\title{
NEUROENDOCRINE AND METABOLIC EFFECTS OF GENERAL ANAESTHESIA AND GRADED HAEMORRHAGE*
}

\author{
Aluen B. Dobkin, m.d., Peter H. Byles, m.b., and John F. Nevilue, Jr., M.D. $\nmid$
}

There is a circumstance attending accidental injury which does not belong to disease, namely, that the injury done has, in all cases, a tendency to produce both the disposition and means of cure.

-John Hunter, 1861

IN A PREviously heALTHX PERSON, physical injury is said to initiate a series of metabolic and endocrine processes which are associated with recovery and normal convalescence. ${ }^{1}$ Many years ago, it was shown that simple haemorrhage alone may also initiate metabolic changes which are simply reflected by an increased concentration of nitrogen in the urine; and recently Moore has reported on his comprehensive studies of this subject. ${ }^{2}$ Cannon recognized the concept of a neuroendocrine response to stress and described an increase in the activity of the sympathetic nervous system and in the output of epinephrine-like substances. In our time, Hans Selye attempted to find a single explanation for the endocrine and metabolic response to stress and postulated that increased adrenocortical activity initiated and controlled the total body response to stress. ${ }^{3}$

Numerous studies have been done to determine the haemodynamic effects of the stress caused by haemorrhage with and without the overlying effect of general anaesthesia. ${ }^{4-9}$ Only in the past few years have studies been reported on the effect of this combination on the reflexogenic areas, ${ }^{10,11}$ the liver and anaerobic metabolism, ${ }^{12,13}$ the heart, ${ }^{14}$ the spinal cord and reticular activating system, ${ }^{16}$ the respiratory system, ${ }^{16-18}$ and the neuroendocrine system. ${ }^{10}$ It appears as if general anaesthesia by itself with thiopental, diethyl ether, and cyclopropane might produce a stress response, but this is not easily shown by measurement of corticosteroids in the blood. $20-21$

This report deals with a continuation of our systematic study of some neuroendocrine and metabolic effects of general anaesthesia ${ }^{22}$ with particular reference to the influence of graded severe haemorrhage.

\section{Materitals and Methods}

Serial crossover tests were carried out on 10 trained male dogs each weighing 25 to $30 \mathrm{~kg}$. Every animal received a general anaesthetic ten times, one every two to three weeks in rotation, with the anaesthetics for maintenance as shown in Table I.

-From the Anesthesiology and Cardiovascular Surgery Laboratories, State University of New York, Upstate Medical Center, Syracuse, New York, U.S.A. Supported by grants-in-aid from Abbott Laboratories, Ayerst Laboratories, McNeil Laboratories, E. R. Squibb \& Son, and U.S.P.H.S. grant 05402-04,5.

†Dr. Neville is Associate Professor of Cardiovascular Surgery. 
TABLE I

Agents Used for Maintenance of Deep Anaesthesia for 120 Minutes Following Induction with 20 Mg./Kg. ThioPENTAL

Respiration controlled at $350 \mathrm{ml} . / \mathrm{kg} . / \mathrm{min}$. from 0 to 120 minutes. Arterial haemorrhage $15 \mathrm{ml} . / \mathrm{min}$. from 15 th to 90 th minute.

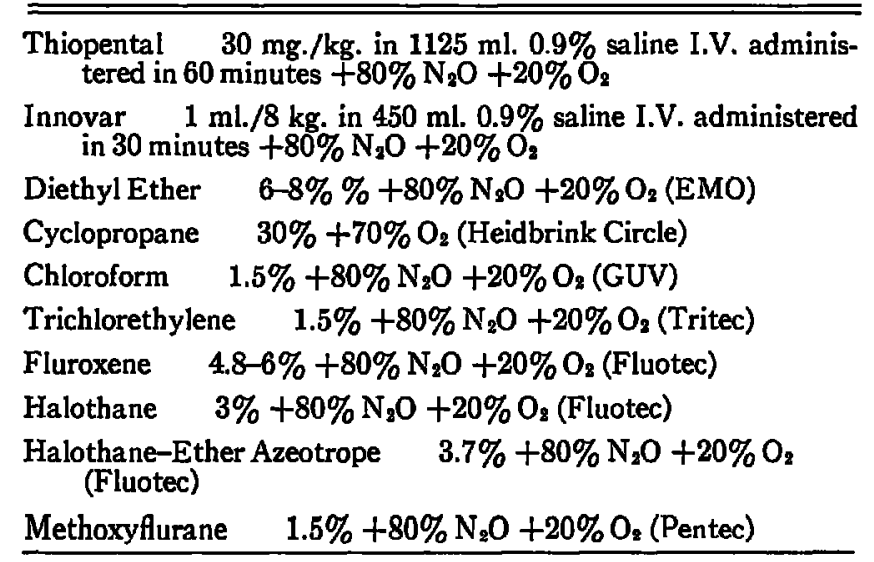

The following procedures were carried out. After an overnight fast, a dog was weighed. An intravenous infusion of 0.9 per cent saline was started in a forepaw vein after drawing a blood sample for estimation of blood sugar, serum potassium, inorganic phosphorus, histamine, serotonin, and catecholamines. Anaesthesia was then induced with $20 \mathrm{mg}$. $/ \mathrm{kg}$. thiopental (2.5\% solution) and an oral cuffed endotracheal tube was inserted and attached to an anaesthetic machine which was set to deliver 80 : 20 nitrous oxide : oxygen. A gas flow was used which was sufficient to provide a minute volume of $350 \mathrm{ml} . / \mathrm{kg}$. (checked with a Wright Respirometer) in a non-rebreathing system, and respiration was controlled by a Harvard pump for 120 minutes after beginning maintenance agents, except with cyclopropaneoxygen with which a semi-closed system was employed. Before beginning maintenance, an E.C.G. lead was connected and was monitored throughout; a catheter was inserted to drain the urinary bladder and gravity collection of urine was arranged using a calibrated trap bottle, and a 19-gauge needle or catheter was inserted into the femoral artery and attached to a damped anaeroid manometer for continuous measurement of the mean arterial blood pressure. When the above arrangements were completed, an arterial blood sample was drawn anaerobically for measurement of $\mathrm{pH}, \mathrm{P}_{\mathrm{aco}}, \mathrm{P}_{\mathrm{aO}_{2}}, \mathrm{~S}_{\mathrm{nO}_{2}}$, and haematocrit. Freeflowing arterial blood was then collected for measurement of whole blood lactate, pyruvate, and blood water content. The animal was given $2 \mathrm{mg} . / \mathrm{kg}$. heparin intravenously, and then the saline infusion drip was regulated to deliver $15 \mathrm{ml}$. per minute. Fifteen minutes after maintenance of anaesthesia was started, $15 \mathrm{ml}$. of arterial blood was withdrawn from the animal into an ACD blood collection bottle every minute until the mean arterial blood pressure fell below $40 \mathrm{~mm}$. Hg, or until 90 minutes of maintenance of anaesthesia had elapsed. The anaesthetic was continued at the same level for an additional 30 minutes, then 
terminated. Venous and arterial blood samples were drawn again for the estimations listed above. The respirator was turned off and 100 per cent oxygen was insufflated through the endotracheal tube until the animal was wide awake. During the hour immediately following the end of anaesthesia, the blood removed was reinfused intravenously along with $500 \mathrm{mg}$. sodium ampicillin (Polycillin ${ }^{\otimes}$ ) and $10 \mathrm{mg} . / \mathrm{kg}$. methylprednisolone sodium succinate (Solumedrol $\left.{ }^{(}\right)$. The time from the end of anaesthesia until the dog was able to raise its head and to ambulate was noted, and notes were kept of the condition of the dog for the following two weeks. Laboratory procedures for analyses of blood samples were identical to those previously reported. ${ }^{22}$

\section{Results}

The mean effect of graded haemorrhage on the heart rate, mean arterial blood pressure (MABP), and urine output for the dogs during general anaesthesia is shown in Figures 1 to 10. Each dog survived all of the tests. Observe that the initial administration of thiopental $(20 \mathrm{mg} . / \mathrm{kg}$.) for preparation of the animal caused a small rise in the heart rate and little or no persistent reduction in the MABP.

\section{Heart Rate}

During the 15 minutes before graded haemorrhage, the heart rate decreased initially and then increased with the haemorrhage during thiopental (marked), Innovar (marked), cyclopropane (slight), fluorexene, trichlorethylene, and halothane-ether azeotrope (slight). During diethyl ether, there was a persistent increase in the heart rate; during chloroform, there was a persistent decrease in the heart rate, and during methoxyflurane, the heart rate remained steady with haemorrhage after an initial slowing.

\section{Mean Arterial Blood Pressure}

During the 15 minutes before graded haemorrhage, MABP decreased with thiopental (slight), Innovar (marked), cyclopropane (slight), chloroform (slight), halothane, halothane-ether azeotrope, and methoxyflurane. With diethyl ether, fluroxene, and trichlorethylene, MABP rose slightly. With graded haemorrhage, MABP fell less than 25 per cent with thiopental, diethyl ether, cyclopropane and fluroxene; 32 per cent with halothane-ether azeotrope; 34 per cent with Innovar; 38 per cent with halothane; 42 per cent with chloroform; 43 per cent with trichlorethylene and 50 per cent with methoxyflurane. During the 30 minutes of anaesthesia following the haemorrhage, the blood pressure rose slightly with all agents except cyclopropane, fluroxene and chloroform.

E.C.G.

No persistent serious ventricular arrhythmias occurred during these tests.

\section{Urine Output}

There was marked suppression of urine drainage during all the tests. During 
the 120 minutes of anaesthesia, a mean volume of less than $60 \mathrm{ml}$. of urine was collected with Innovar (54), diethyl ether (38), chloroform (46), trichlorethylene (43), and halothane-ether azeotrope (46). Urine drainage was moderately suppressed with thiopental (75), cyclopropane (60), fluroxene (71), halothane (81), and methoxyflurane (77).

Mean values, and standard error of the mean, of the blood analyses for ten experiments with each anaesthetic are shown in Tables II to V. A summary of the changes appears in Table VI; the significant ones are circled. Figures 11 to 15 depict the mean changes which occurred in appropriate graphs.

\section{Blood Gases, Haematocrit, and Blood Water (Table II)}

There was an increase in fixed acids during all of the anaesthetics. This change was most evident with diethyl ether, but was also appreciable with chloroform, trichlorethylene, fluroxene, halothane, halothane-ether azeotrope, and methoxyflurane. No fixed acids accumulated during cyclopropane anaesthesia, but there was an evident respiratory acidosis as reflected by a decrease in the blood $\mathrm{pH}$ and a rise in the $\mathrm{P}_{\mathrm{aCO}}$ (Fig. 11). $\mathrm{P}_{\mathrm{aO}}$ and $\mathrm{S}_{\mathrm{aO}_{2}}$ values were within normal limits in all the tests (Fig. 12). As expected, the haematocrit fell approximately 25 per cent in each experiment, but the change was considerably less with diethyl ether $(\sim 20 \%)$ and more with halothane $(\sim 33 \%)$ and methoxyflurane $(\sim 37 \%)$. Whole blood water increased with all agents except halothane and halothane-ether azeotrope.

\section{Blood Sugar, Serum Potassium, and Serum Inorganic Phosphorus (Table III)}

Blood sugar rose during all of the tests. The change was considerable with diethyl ether, chloroform, and fluroxene, and slight with trichlorethylene, halothane-ether azeotrope, and methoxyflurane.

Serum potassium was reduced moderately in all of the tests while serum inorganic phosphorus was reduced slightly with all agents except diethyl ether, cyclopropane, and halothane-ether azeotrope. None of these changes were considered to be significant (Figure 13).

\section{Lactate, Pyruvate, L/P Ratio, and Excess Lactate (Table IV)}

Although there was an appreciable increase in the whole blood lactate and pyruvate in all the tests, diethyl ether was the only anaesthetic which caused a consistent marked increase in the L/P ratio and excess lactate (Figure 14).

\section{Biogenic Amines (Table V)}

There were no appreciable consistent changes in the blood levels of histamine and serotonin. Plasma epinephrine rose with Innovar (29\%) and cyclopropane (40\%), and plasma norepinephrine rose with halothane (30\%), but these changes were not considered significant (Figure 15).

Figure 16 shows that there is evidently no relationship between changes in blood sugar, lactate and pyruvate, and the catecholamines during any of the general anaesthetics (Table VI). 

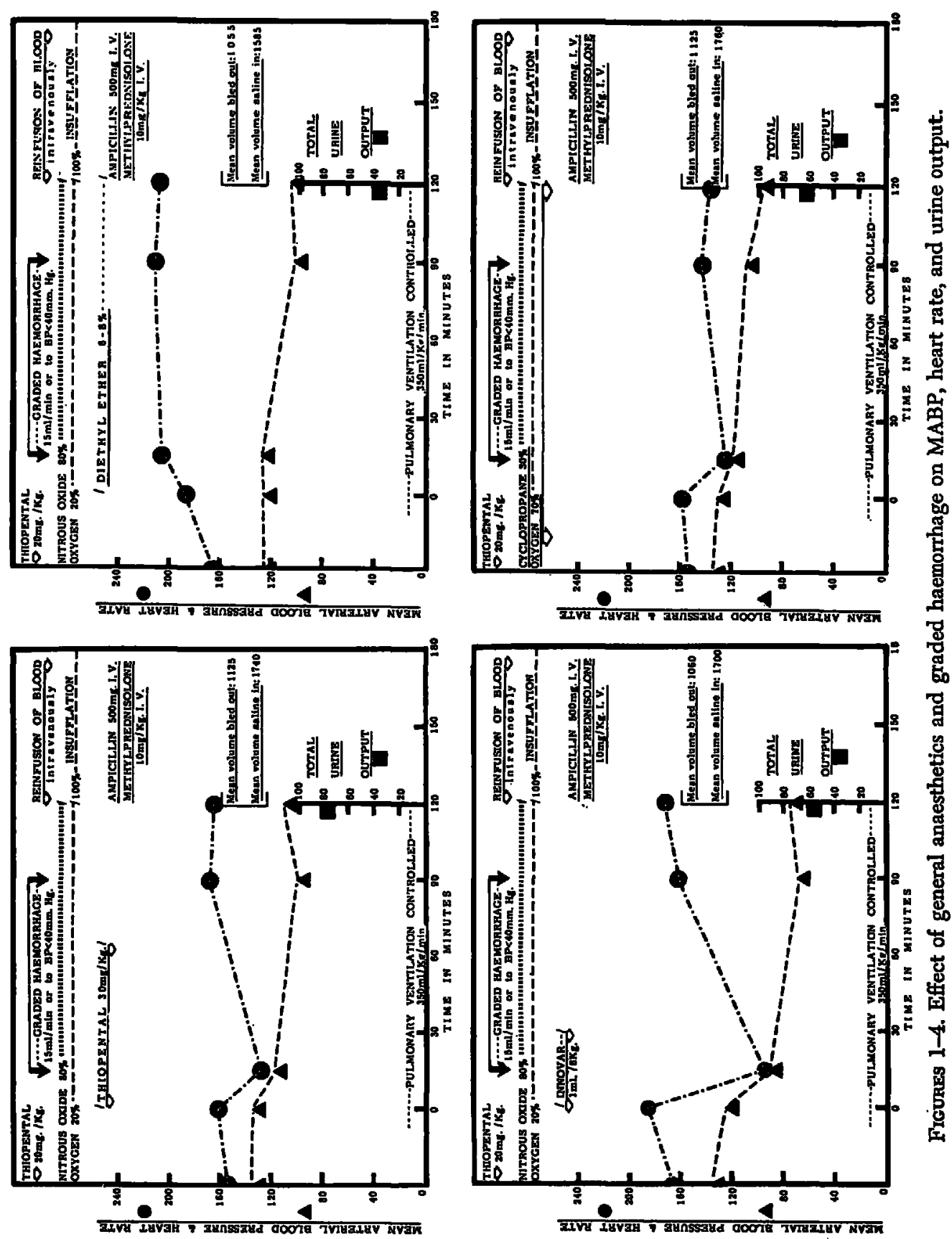

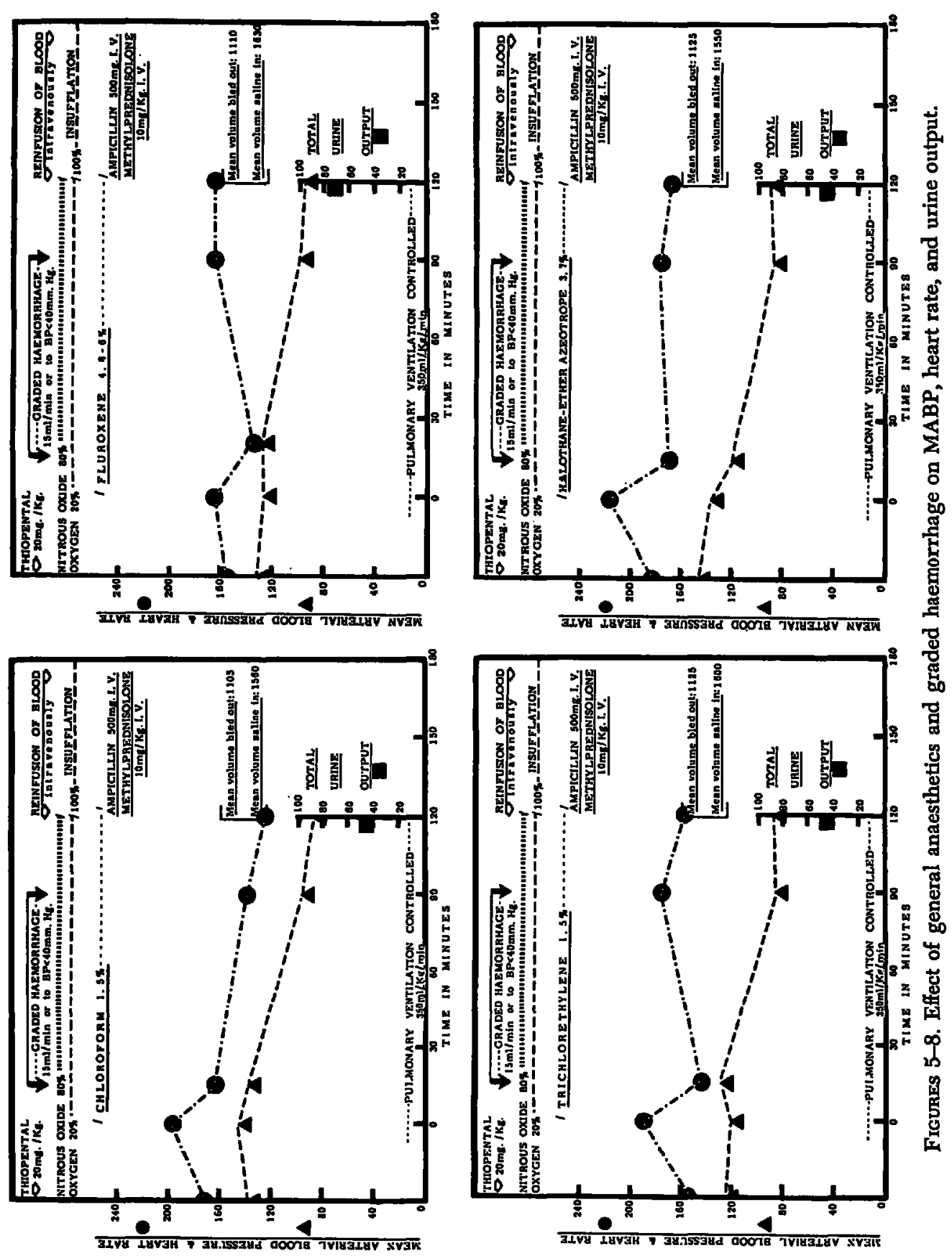

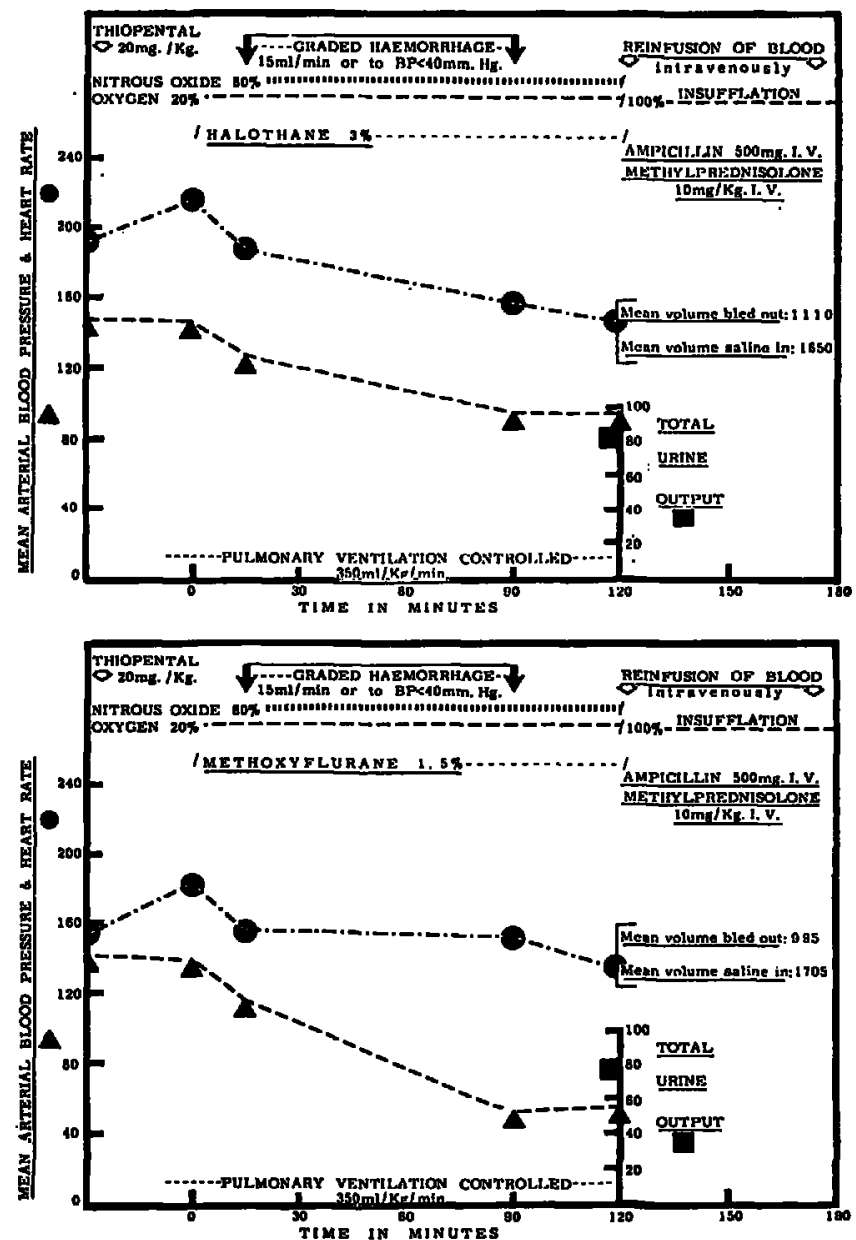

Ficures 9 \& 10. Effect of general anaesthetics and graded haemorrhage on MABP, heart rate, and urine output. 

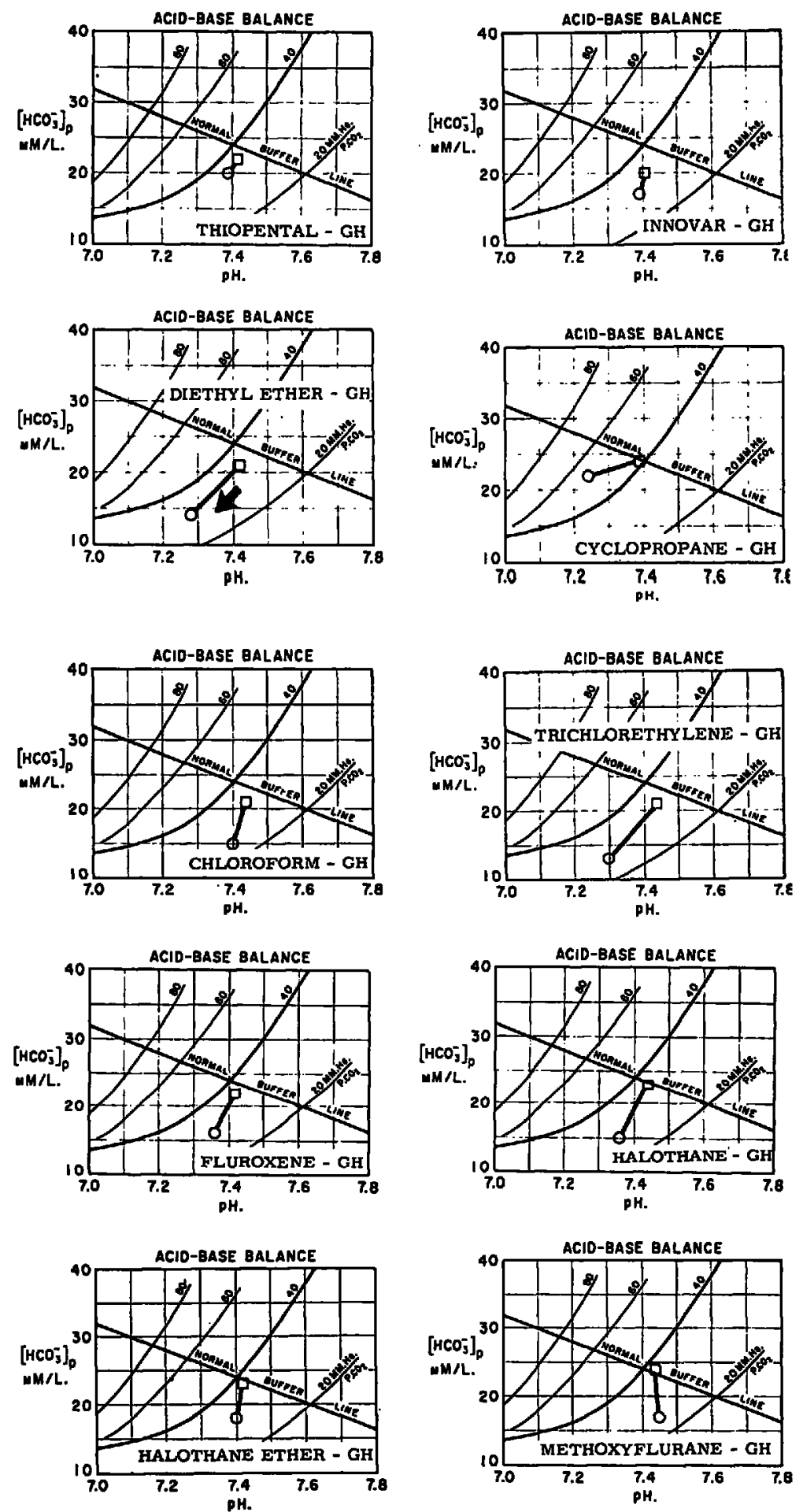

Ficune 11. Alterations in $\mathrm{pH}, \mathrm{P}_{\mathrm{aCO}}$, and plasma bicarbonate during general anaesthesia and graded haemorrhage. 

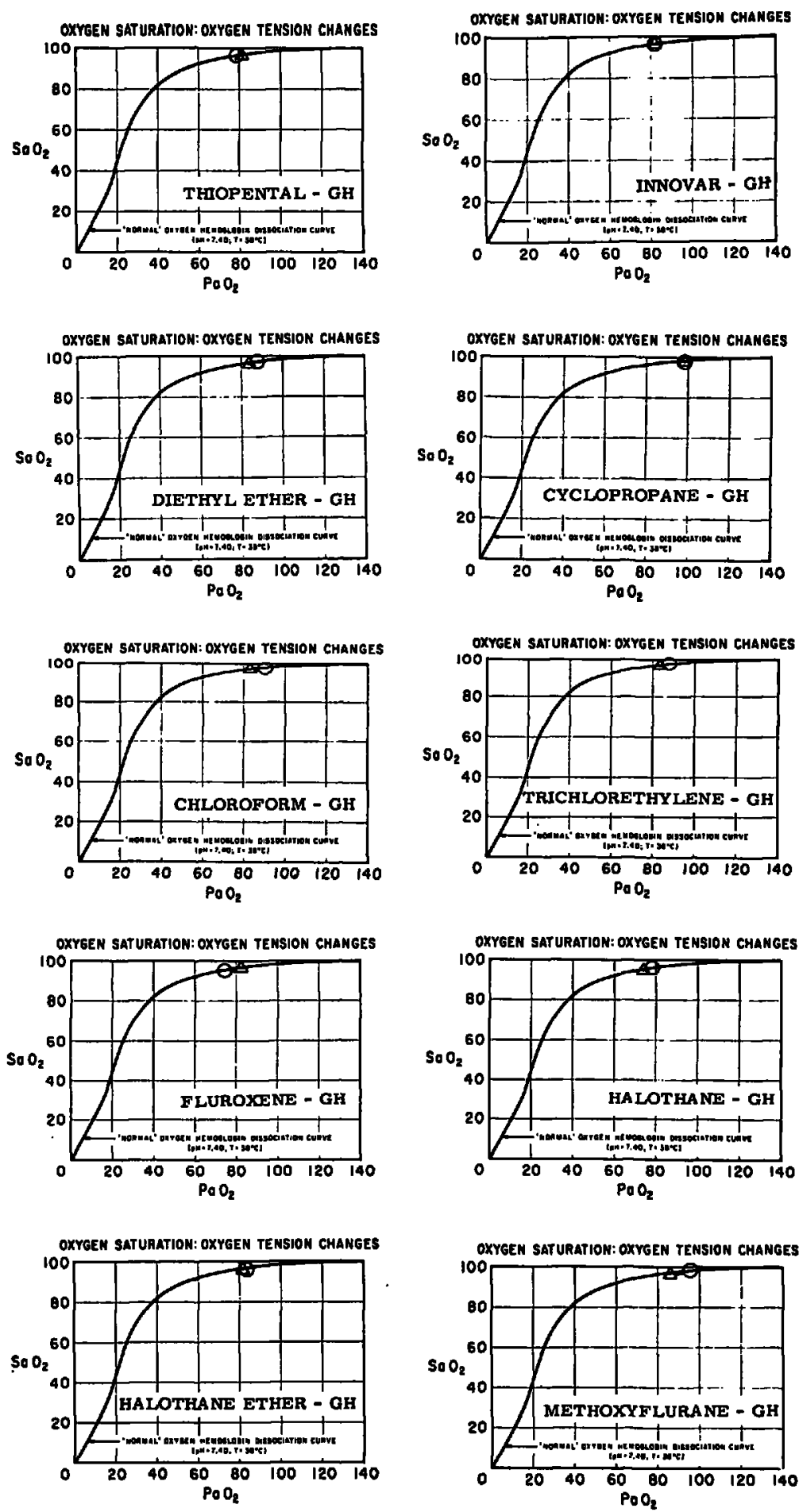

Ficune 12. Alterations in $\mathrm{P}_{\mathrm{aOz}}$ and $\mathrm{S}_{\mathrm{aO} 2}$ during general anaesthesia and graded haemorrhage. 


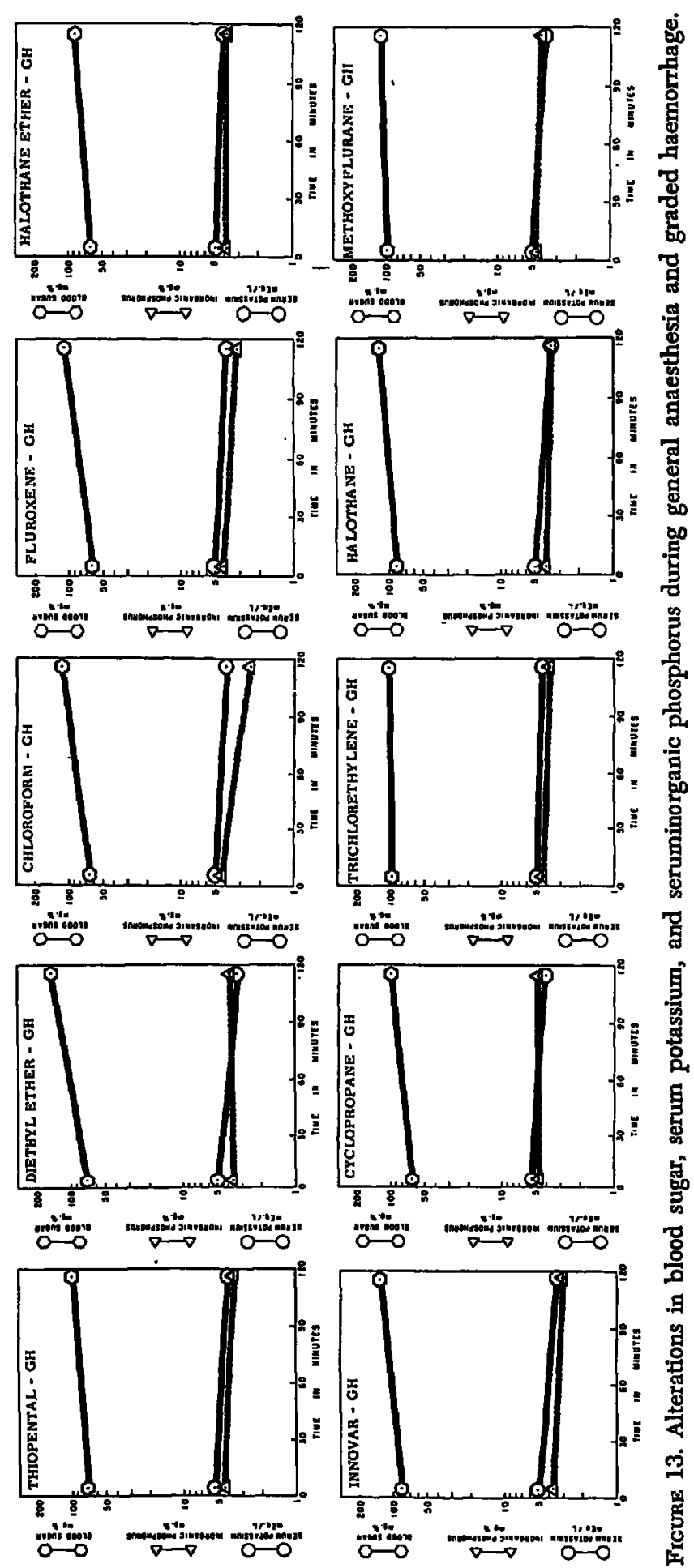



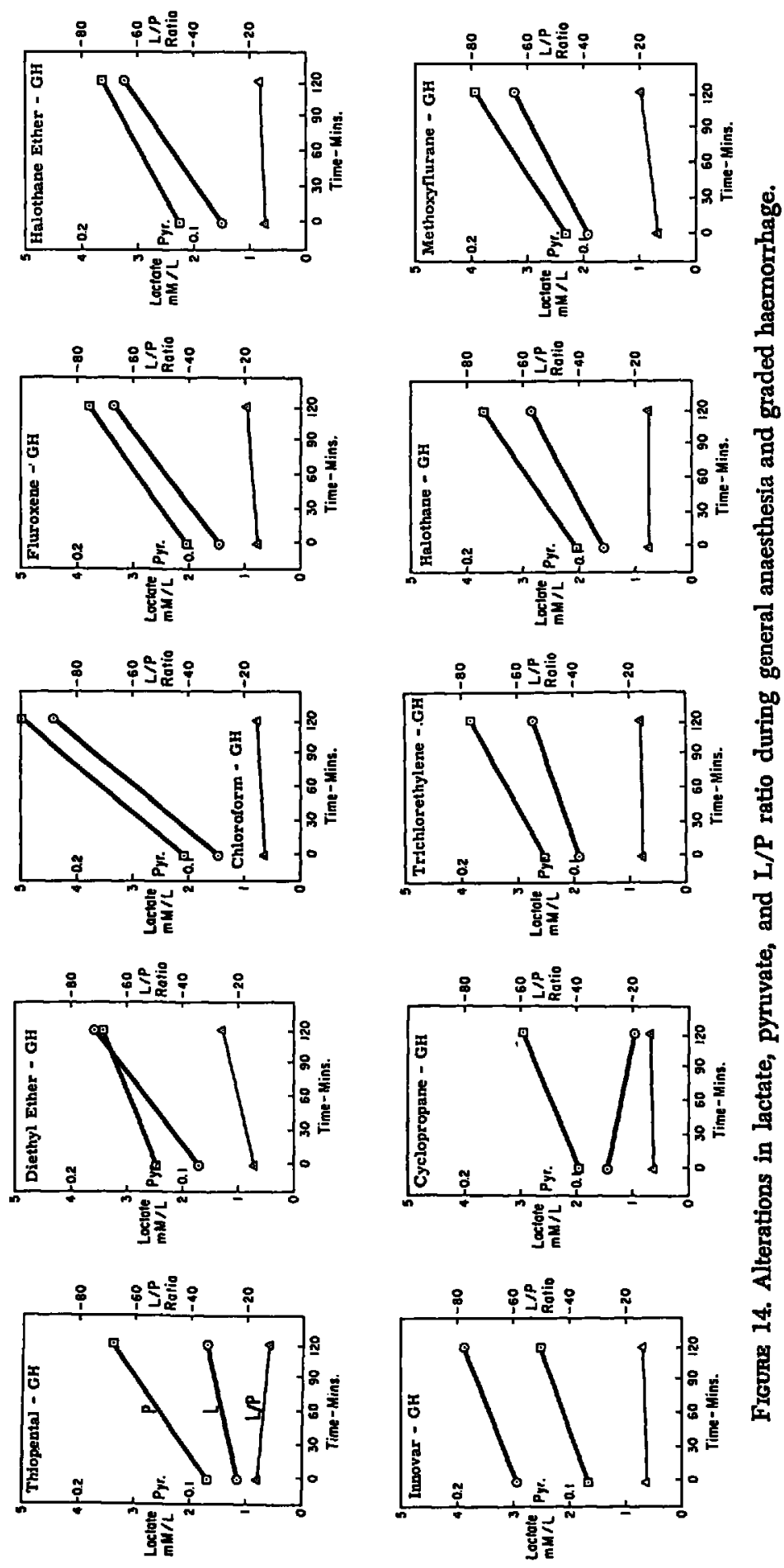

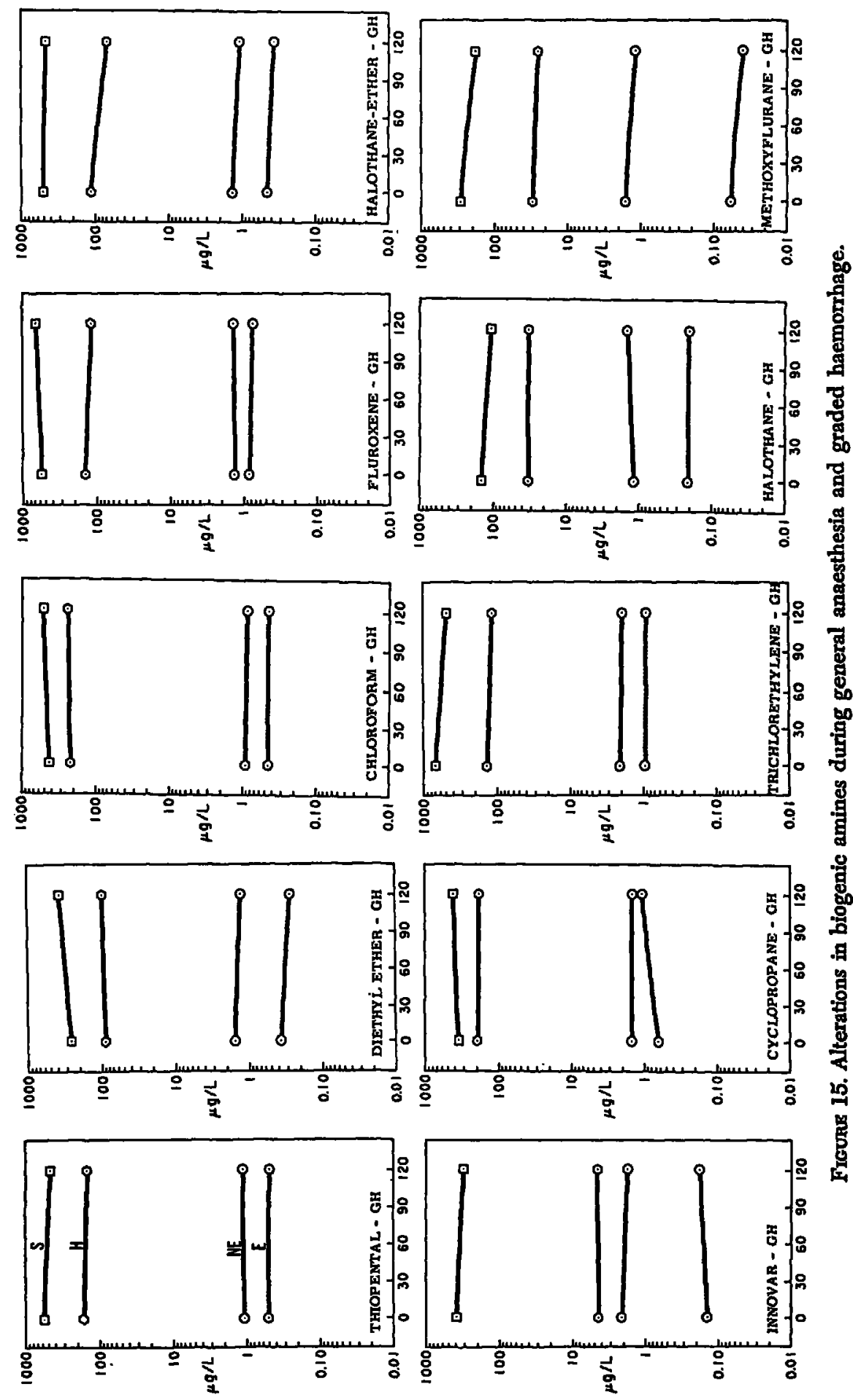

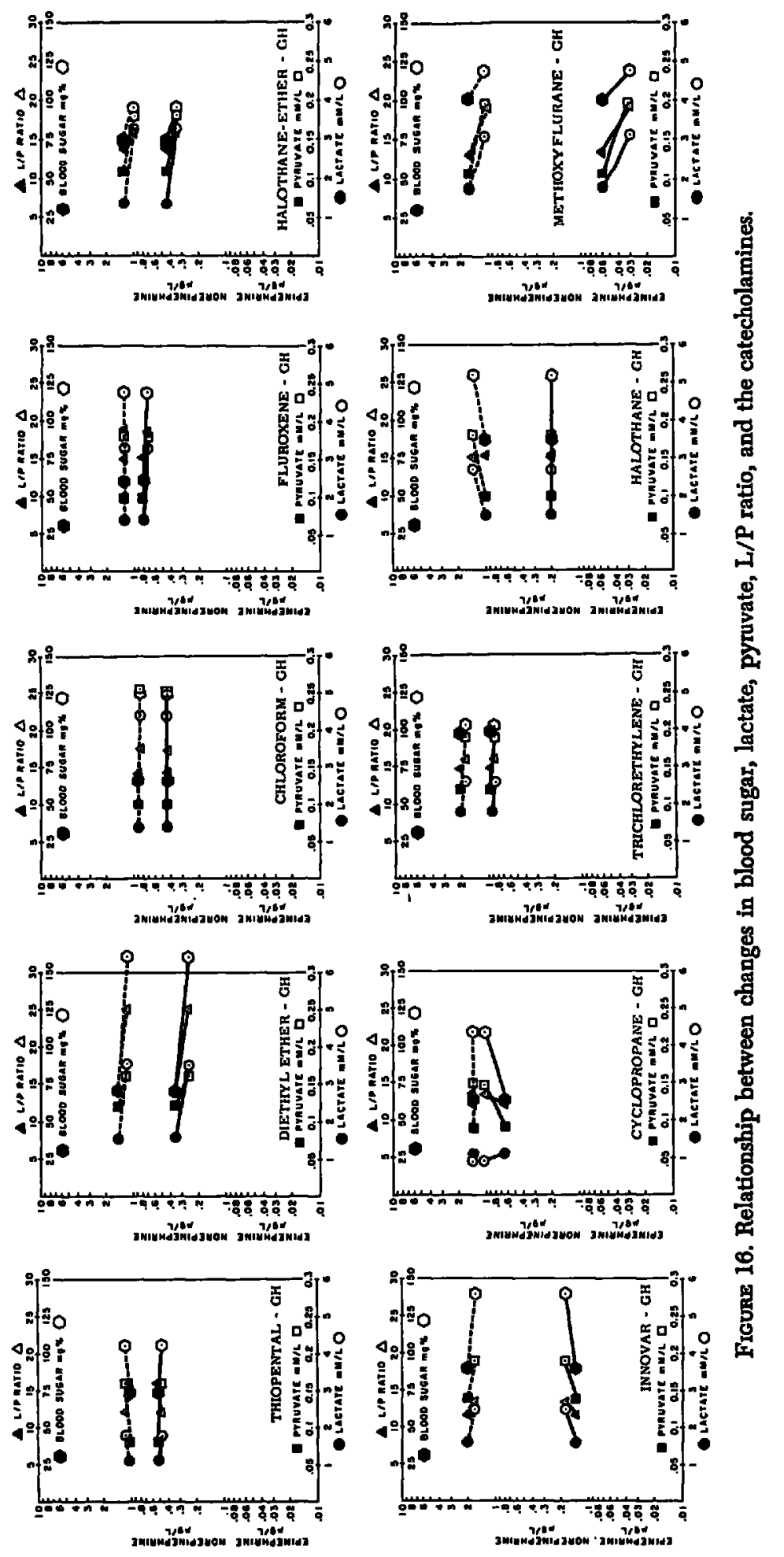


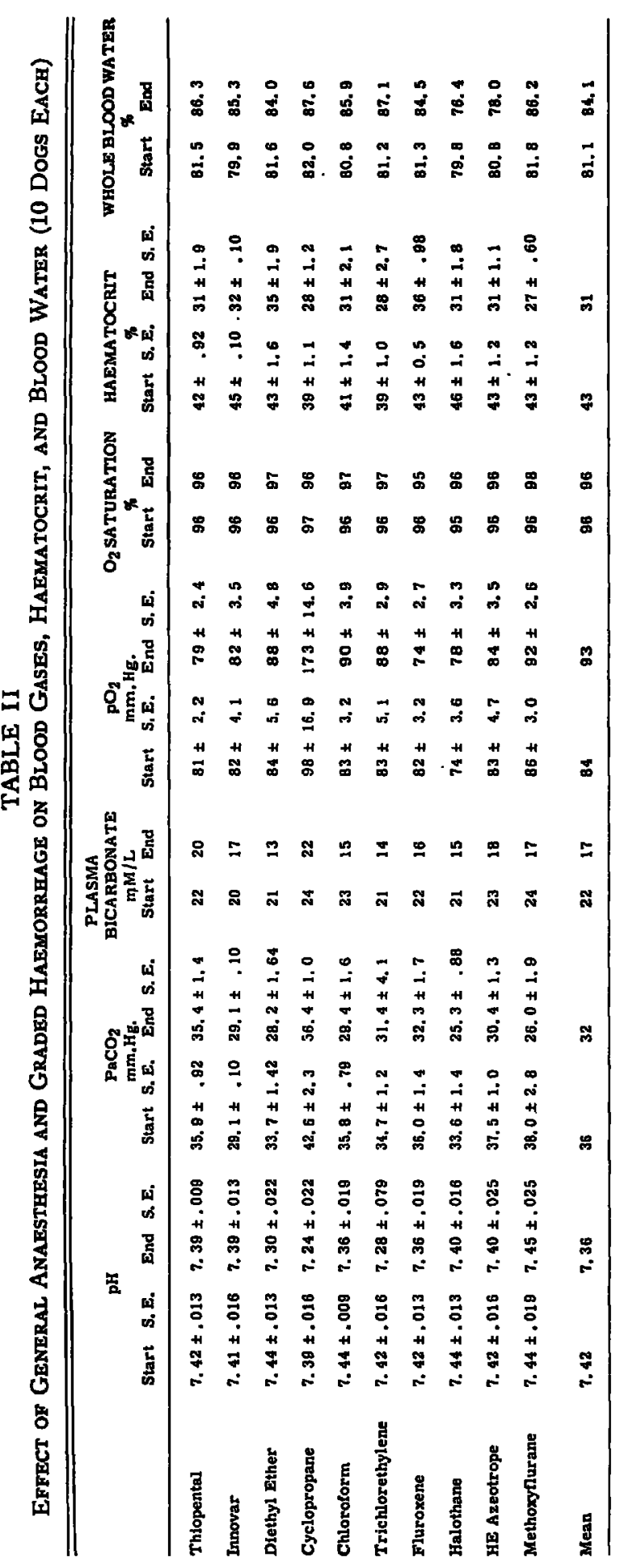


TABLE III

Effect of General anaesthesia and Graded Haemorrhage on Blood Sugar, Serum Potassium, and Serum Inorganic Phosphorus (10 Dogs Each)

\begin{tabular}{|c|c|c|c|c|c|c|}
\hline \multirow{3}{*}{ Thiopental } & \multirow{2}{*}{$\begin{array}{r}\text { BLOOD } \\
\text { mg. } \\
\text { Otart S, E. }\end{array}$} & \multirow{2}{*}{$\begin{array}{l}\text { SUGAR } \\
\text { End S.E. }\end{array}$} & & \multicolumn{2}{|c|}{$\begin{array}{l}\text { INORGAMIC } \\
\text { PHOSPHORUS } \\
\text { me. } \%\end{array}$} \\
\hline & & & Start 8. E. & End S, E. & Start S. E. & End S, E, \\
\hline & $73 \pm 4,3$ & $105 \pm 4.1$ & $5,3 \pm .12$ & $3.8 \pm .22$ & $4.4 \pm .23$ & $3.5 \pm .18$ \\
\hline Innovar & $88 \pm 3.8$ & $138 \pm 4.5$ & $5.2 \pm .01$ & $3.4 \pm .01$ & $3.9 \pm .02$ & $3.0 \pm .02$ \\
\hline Dlethyl Ether & $71 \pm 5.2$ & $160 \pm 16.1$ & $5,1 \pm .36$ & $3,3 \pm, 18$ & $3.7 \pm .20$ & $3,8 \pm .45$ \\
\hline Cyclopropane & $66 \pm 2.7$ & $109 \pm 11.7$ & $5.5 \pm .18$ & $4.2 \pm .10$ & $4.8 \pm .28$ & $4.8 \pm .23$ \\
\hline Chloroform & $67 \pm 3.4$ & $184 \pm 0.7$ & $5.3 \pm .11$ & $4.0 \pm .12$ & $4.6 \pm .20$ & $3.4 \pm .20$ \\
\hline Trichlorethylene & $98 \pm 11.0$ & $102 \pm 4.3$ & $5.0 \pm .09$ & $4.2 \pm .13$ & $4.3 \pm .35$ & $3.6 \pm .18$ \\
\hline Fluroxene & $63 \pm 4,0$ & $118 \pm 11.0$ & $5.2 \pm .09$ & $4,0 \pm .23$ & $4.4 \pm .14$ & $3,2 \pm .21$ \\
\hline Halothane & $87 \pm 3.2$ & $129 \pm 6.5$ & $5.1 \pm .13$ & $3.6 \pm .10$ & $4.0 \pm .22$ & $3.6 \pm .25$ \\
\hline HE Azeotrope & $74 \pm 6.5$ & $91 \pm 8.4$ & $4.8 \pm .17$ & $4.2 \pm .31$ & $3,9 \pm .18$ & $4.0 \pm .38$ \\
\hline Methoxyflurane & $101 \pm 4.0$ & $119 \pm 4.8$ & $5.0 \pm .23$ & $3.8 \pm .22$ & $4.7 \pm .20$ & $4.2 \pm .28$ \\
\hline
\end{tabular}

TABLE IV

Effect of General Anaesthesia and Graded Haemorrhage on Lactate, Pyruvate, L/P RATIO, AND EXCESS LACTATE (10 DOGS EACH)

\begin{tabular}{|c|c|c|c|c|c|c|c|}
\hline & \multicolumn{2}{|c|}{$\begin{array}{l}\text { LACTATE } \\
\mathrm{mM} / \mathbf{L}\end{array}$} & \multicolumn{2}{|c|}{$\begin{array}{l}\text { PYRUVATE } \\
\mathrm{mM} / \mathrm{L}\end{array}$} & \multicolumn{2}{|c|}{ L/P RATIO } & \multirow[t]{2}{*}{$\begin{array}{l}\text { FXcess } \\
\text { LACTATE } \\
\text { mM/L }\end{array}$} \\
\hline & Start S. E. & Fnd $\mathbf{S}, \mathbf{E}$ & Start S. E. & End $S . E$. & Start S. E. & End S, E. & \\
\hline Thiopental & $1.127 \pm .042$ & $1.744 \pm .217$ & $.085 \pm .008$ & $.169 \pm .032$ & $16.4 \pm 2.08$ & $12.2 \pm 1.20$ & 0 \\
\hline Innovar & $1.642 \pm .025$ & $2.501 \pm .024$ & $.146 \pm .082$ & $.192 \pm .086$ & $11.8 \pm .031$ & $13.5 \pm .082$ & .317 \\
\hline Diethyl Ether & 1. $645 \pm .083$ & $3.567 \pm .440$ & $.122 \pm .008$ & $.168 \pm .018$ & $14.0 \pm .83$ & $25.8 \pm 2.7$ & 1,264 \\
\hline Cyclopropane. & $1.139 \pm .059$ & $.928 \div .084$ & $.087 \pm .008$ & $.146 \pm .060$ & $12.1 \pm .81$ & $13.4 \pm 1.8$ & 0 \\
\hline Chloroform & $1.461 \pm .079$ & $4,470 \pm .407$ & $.104 \pm .006$ & $.252 \pm .015$ & $14.3 \pm .45$ & $17.7 \pm 1.25$ & .893 \\
\hline Trichlorethylene & $1.885 \pm .279$ & $2.671 \pm .278$ & $.126 \pm .022$ & $.191 \pm .020$ & $14.5 \pm 1.49$ & $16,0 \pm 1.18$ & 0 \\
\hline Fluroxene & $1.437 \pm .110$ & $3.336 \pm .348$ & $.102 \pm .009$ & $.189 \pm .021$ & $15.4 \pm 1.11$ & $18.6 \pm .68$ & .561 \\
\hline Halothane & $1.586 \pm .121$ & 2. $786 \pm .274$ & $.103 \pm .012$ & $.184 \pm .022$ & $15,4 \pm 3,00$ & $15.2 \pm 2.93$ & $\mathbf{0}$ \\
\hline HE Azeotrope & $1.493 \pm .120$ & $3,216 \pm .379$ & $.112 \pm .008$ & $.281 \pm .016$ & $14.1 \pm 1,10$ & $16.3 \pm 1.4$ & .750 \\
\hline Methoxyflurane & $1.885 \pm .356$ & $3.194 \pm .152$ & $.114 \pm .023$ & $.186 \pm .013$ & $13.5 \pm .92$ & $18.4 \pm 3.6$ & .128 \\
\hline
\end{tabular}




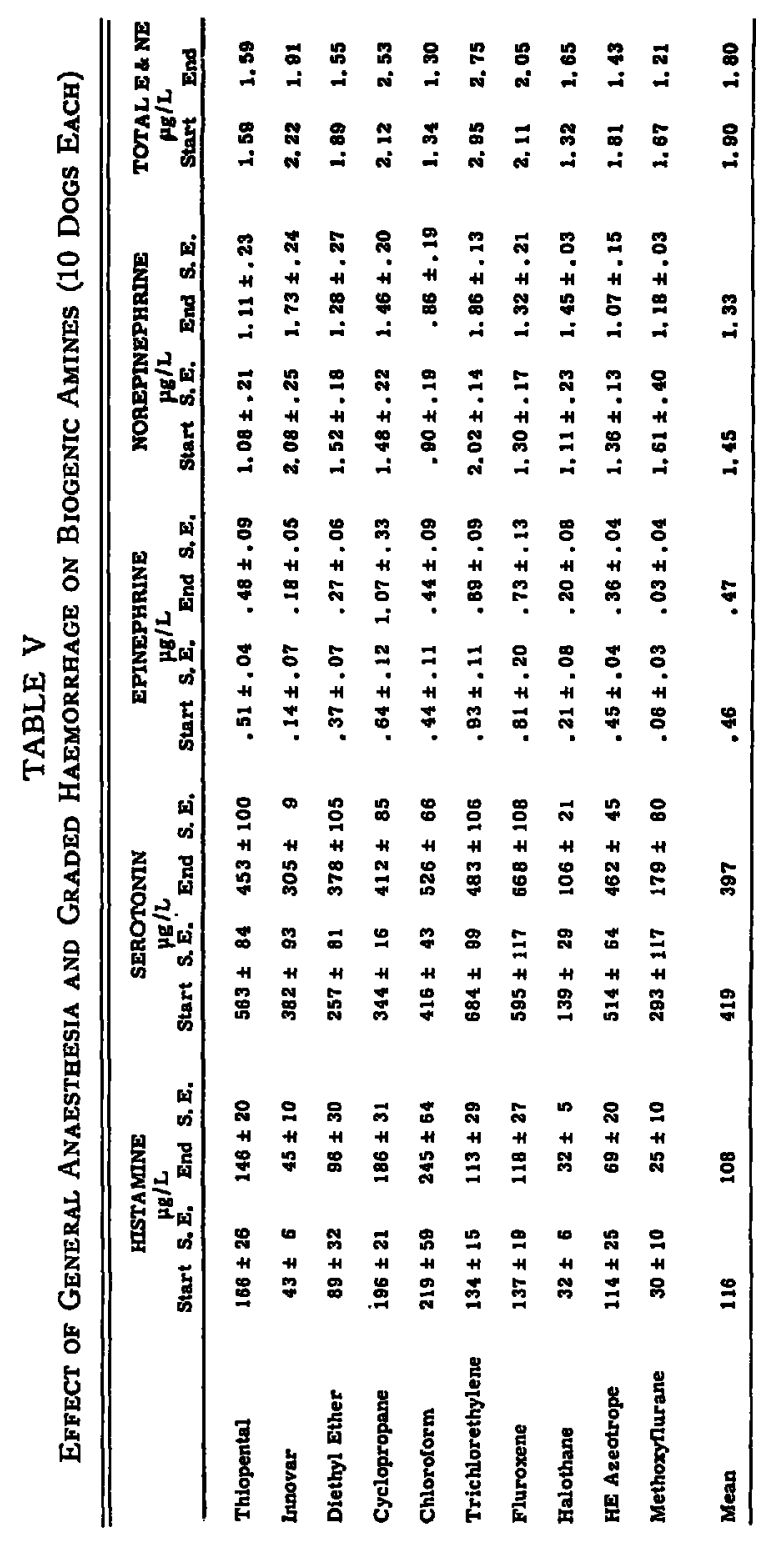




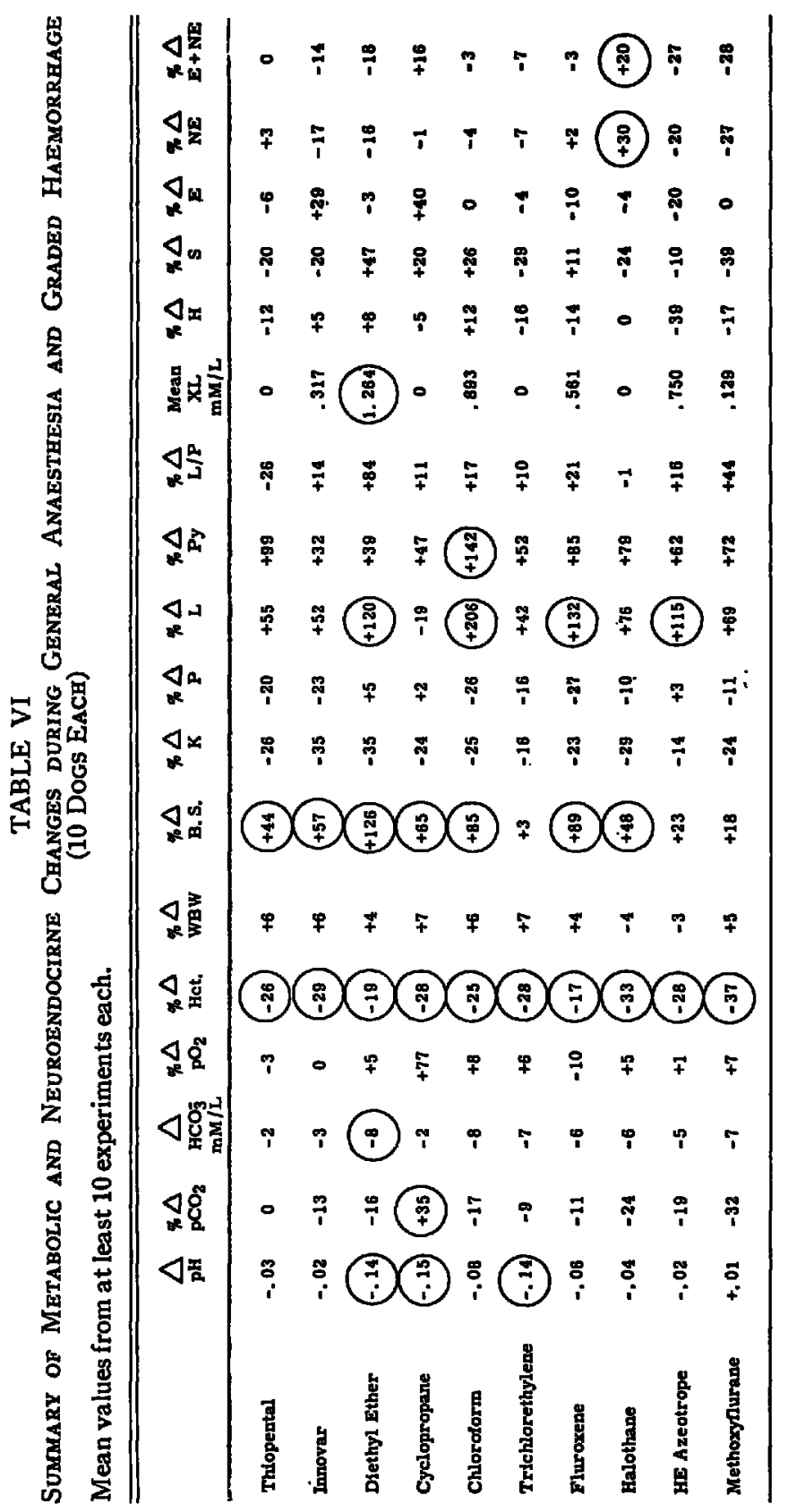




\section{Discussion}

Much of the data reported in the literature regarding the stressful effect of haemorrhage deal with a standardized method of producing "irreversible haemorrhagic shock." The procedure is usually some modification of the following: Dogs are anaesthetized with a relatively large dose of a long-acting intravenous barbiturate (usually barbital). It is usually not clear whether the animals are well-ventilated during the anaesthetic. The animals are then rapidly bled from the femoral artery by removing $50 \mathrm{ml}$. of blood per minute until the arterial blood pressure falls to $50 \mathrm{~mm}$. $\mathbf{H g}$; they are maintained at this level for 90 minutes. By further bleeding, the blood pressure is then lowered to $30 \mathrm{~mm}$. $\mathrm{Hg}$ and maintained at this level for anywhere from 45 minutes to 4 hours, then all the blood removed is reinfused. Following reinfusion, almost all animals expire. During demise, there is a progressive fall in plasma volume, rise in haematocrit, and rise in plasma haemoglobin. At autopsy, haemorrhagic necrosis of the small bowel mucosa is usually observed. This "model" is quite impractical except perhaps in studying the effect of sudden laceration of large arteries.

The haemorrhage procedure we carried out matches the clinical surgical situation more closely, and the anaesthetic techniques employed with each of the 10 general anaesthetics were carried out in a manner that one would use clinically.

In our previous study, it appeared evident that in the absence of surgical trauma none of the general anaesthetics, except perhaps deep diethyl ether, produce any serious long-lasting disturbances that fulfil the classic picture of the stress response.,22 For clinical purposes, therefore, the skilful use of general anaesthesia may be regarded as a very minor form of stress, which will not provoke any appreciable metabolic or neuroendocrine response.

From the present studies, it appears that graded arterial bleeding is not well reflected by the mean arterial blood pressure with thiopental, Innovar, diethyl ether, cyclopropane, or fluroxene anaesthesia, whereas during anaesthesia with chloroform, trichlorethylene, halothane, halothane-ether azeotrope, and methoxyflurane, there is a close to parallel reduction in blood pressure as the circulating blood volume is depleted. The latter change is of obvious practical importance to the clinician. It was interesting to note also that the mean blood pressure was rapidly restored by a small blood volume replacement with the first five agents, while a more substantial restoration of blood volume was required with the latter five. A rise in the heart rate obviously reflected progressive blood loss during thiopental, Innovar, fluroxene and trichlorethylene. No such change was seen with diethyl ether, cyclopropane, halothane, halothane-ether azeotrope, and methoxyflurane.

Evidently, the degree of graded haemorrhage, or its replacement is not well represented by measurement of the mean arterial blood pressure or heart rate with diethyl ether or cyclopropane, whereas with the others, changes in either blood pressure or heart rate are reasonably accurate indicators. Similar observations have been reported for a comparison of cyclopropane and halothane ${ }^{7}$ and in a comparison of halothane and methoxyflurane. ${ }^{\mathrm{B}}$

All of the general anaesthetics caused a marked suppression of urine excretion, which was evidently aggravated by haemorrhagic hypotension, shown by the 
fact that the oliguric response was greater in these experiments than we observed in our previous experiments in which there was no blood loss. ${ }^{22}$ The suppression of urine excretion is most acute during anaesthesia with diethyl ether, chloroform, trichlorethylene, and halothane-ether azeotrope.

The ultimate survival of all the animals following the repeated stress of deep anaesthesia and considerable depletion of circulating blood volume may be attributed in part to support of pulmonary ventilation during the experiments, administration of 100 per cent oxygen during recovery, and early replacement of shed blood with the addition of a large dose of a corticosteroid and an antibiotic. $28,24,25$

The authors were unable to find comparable data on the effect of graded haemorrhage, during general anaesthesia, on the metabolic and neuroendocrine parameters reported here. It appears from our study, that when approximately 50 per cent of a dog's circulating blood volume is removed gradually from an artery during 90 minutes of moderately deep anaesthesia, as long as pulmonary ventilation is maintained at a normal level and intravenous 0.9 per cent saline infusion is provided at approximately the same rate as the blood is removed, no deterioration of the circulation is apparent even when anaesthesia is maintained for an additional 30 minutes before replacement of the blood. However, the following changes in the blood are likely to occur: Metabolic acidosis will develop with all agents except thiopental, Innovar, and cyclopropane. Respiratory acidosis will occur with cyclopropane unless hyperventilation is provided in a closed system. Whole blood lactate will increase with all agents except cyclopropane, but the $L / P$ ratio and "excess lactate" will only change appreciably with diethyl ether. There will be a rise in blood sugar with all agents, especially during anaesthesia with diethyl ether, chloroform, and fluroxene, while serum potassium will fall with all agents. Serum inorganic phosphorus tends to fall except with diethyl ether, cyclopropane, and the halothane-ether azeotrope. None of the general anaesthetics appeared to cause an appreciable consistent change in any of the biogenic amines.

We were surprised that there was little or no change in the measurements of total plasma catecholamine levels with any of the agents, contrary to the opinion expressed in some reports with reference to anaesthesia with barbiturates, cyclopropane, and diethyl ether; nor can we support the opinion that haemorrhagic hypotension is an important cause of an elevated blood epinephrine, even though the experimental conditions were not strictly comparable to work reported by others. ${ }^{26,27}$

If our observations reflect the true state of affairs with regard to blood levels of the catecholamines, the pervading question of why such an important clinical parameter as mean arterial blood pressure should have remained relatively elevated in the face of considerable haemorrhage-particularly during anaesthesia with thiopental, diethyl ether, cyclopropane, and fluroxene-remains perplexing. The consistent appearance of an elevation of the blood sugar adds to the doubt and confusion, and makes it difficult to provide a logical explanation. However, two recent comprehensive reviews on catecholamines reveal important information which supplies a clue to the answers and helps explain our findings. ${ }^{28,20}$ When epinephrine or norepinephrine is injected (or released) into the circulation, 
many remarkably short-lived physiological responses occur. For instance, a marked elevation of the blood pressure lasts less than five minutes, ${ }^{30}$ while the catecholamine is said to remain present in the whole animal, bound in a chemically unchanged form, for some hours. ${ }^{31}$ Apparently, the only way to identify with certainty the fate of circulating catecholamine is by continuous infusion of tracer amounts of isotopically labelled material ( $H^{\text {s- }}$ catecholamine). Wurtman ${ }^{28}$ suggested that it might be anticipated that processes which delay the disappearance from the blood of a spurt of catecholamine would potentiate its effects. The two most important mechanisms for removing epinephrine and norepinephrine from the blood are uptake into sympathetic nerve endings and enzymatic inactivation by catechol-o-methyl transferase. ${ }^{32}$ Interference with either of these processes may prolong the physiological effects of circulating catecholamines. It has already been shown that the uptake of circulating norepinephrine can be blocked by a drug such as cocaine, resulting in delay in the disappearance of the catecholamines from the blood and in potentiation of the responses to norepinephrine. The o-methylation of circulating epinephrine may also be blocked by a drug such as pyrogallol, enhancing the effect of injected catecholamine and delaying its disappearance from the blood. We remain in the unfortunate position of being unable to locate and measure the relatively few molecules of the catecholamines that may be responsible for physiological and metabolic alterations, and may only suggest that such changes that occur during administration of general anaesthetic agents such as thiopental, diethyl ether, and cyclopropane are likely to be due to one or more of the following alternatives: general release of spurts of very small amounts of catecholamines from the adrenals and sympathetic nerve endings into the circulation, suppression of mechanisms that enzymatically inactivate the small amounts of catecholamines that are normally continuously released into the circulation-allowing accumulation and persistence of physiological and other effects, and block of the uptake at storage sites (sympathetic nerve endings) or enhancement of uptake by receptor sites. What a combination of these factors might do to the measurable blood levels of catecholamines is obviously open to conjecture, even if we ignore the many interrelationships of catecholamines with other endocrine systems. This points to the reason why consistent data on this subject have not appeared in the literature in spite of the very sensitive chemical methods of measurement that are now available.

\section{Summary and Conclusions}

Serial crossover tests were carried out on 10 large, trained male dogs that were moderately deeply anaesthetized for 120 minutes at two-week intervals, with 10 different general anaesthetic agents. From 15 minutes to 90 minutes after maintenance of anaesthesia was begun, the animals were bled from an artery at the rate of $15 \mathrm{ml}$./minute with the aim of reducing the mean arterial blood pressure to $40 \mathrm{~mm}$. Hg. The mean reduction in circulating blood volume was approximately 50 per cent. Anaesthesia was managed in the best way clinically: Pulmonary ventilation was maintained as near normal as possible by controlling the respiration mechanically at $350 \mathrm{ml} . / \mathrm{kg} . / \mathrm{min}$. A non-rebreathing system was used with all agents except cyclopropane, and 20 per cent oxygen was always 
administered. Mean arterial blood pressure, heart rate, E.C.G., and urine output were monitored and recorded, and 0.9 per cent saline infusion was administered intravenously throughout the anaesthetic period. During the hour following anaesthesia, all the blood removed was reinfused intravenously along with methylprednisolone $(10 \mathrm{mg}$. $/ \mathrm{kg}$.) and ampicillin $(500 \mathrm{mg}$.) and 100 per cent oxygen was insufflated through an endotracheal tube until the animal was fully recovered.

Measurement of mean arterial blood pressure reflected blood loss and replacement reasonably well with the halogenated anaesthetics except fluroxene. With thiopental, Innovar, diethyl ether, cyclopropane, and fluroxene, the blood pressure not only failed to decrease in parallel as blood volume depletion became severe, but it was also restored or elevated when there was only partial replacement. The heart rate did not appear to be a satisfactory indication of alterations in blood volume except with the intravenous anaesthetics (thiopental and Innovar) and perhaps also with fluroxene and trichlorethylene. The electrocardiogram did not show any consistent serious derangements relative to any of the anaesthetics or to the degree of haemorrhage. Urine excretion was suppressed by all of the anaesthetics and by the bleeding procedure. This effect was most striking during diethyl ether, chloroform, trichlorethylene, and halothane-ether azeotrope.

The bleeding procedure provoked a trend to metabolic acidosis with all the inhalation agents except cyclopropane. The only other striking metabolic changes observed were a marked rise in blood sugar with diethyl ether and chloroform, and excess lactate with diethyl ether. Blood levels of histamine and serotonin and plasma levels of the catecholamines did not vary appreciably, and there was no apparent direct relationship among the observed measurements of blood sugar, lactate, pyruvate, and catecholamines.

The animals recovered from anaesthesia within one to three hours following reinfusion of blood and were invariably clinically normal within a day after each test. It is likely that the rapid recovery from the stress of the combination of haemorrhage and general anaesthesia may be attributed partly to the use of a relatively large dose of the corticoid and antibiotic drugs.

\section{RésuMÉ}

Nous avons pratiqué une série d'épreuves sur 10 gros chiens mâles, bien entrainés, que nous avons anesthésiés profondément durant 120 minutes, toutes les deux semaines, en utilisant 10 différents anesthésiques. De 15 à 90 minutes après le début de l'anesthésie, on a ouvert une artère et on a saigné ces animaux au rythme de 15 c.c. par minute, dans le but de diminuer la pression artérielle moyenne à 40 millimètres de mercure. La diminution moyenne du volume du sang circulant a été d'environ 50 pour cent. L'anesthésie a été conduite cliniquement de la meilleure manière possible; on a maintenu la ventilation pulmonaire aussi près que possible de la normale en contrôlant mécaniquement la respiration à $350 \mathrm{c} . c . / \mathrm{kg} . / \mathrm{min}$. On a utilisé une techniques sans réinspiration pour tous les agents sauf le cyclopropane, et on a toujours administré 20 pour cent d'oxygène. On a enregistré la pression artérielle moyenne, le rythme cardiaque, l'électrocardiogramme et le débit urinaire, et on a injecté par voie veineuse du sérum physiologique durant toute l'anesthésie. Durant l'heure qui a suivi l'anesthésie, 
tout le sang enlevé a été réinjecté dans les veines en même temps que de la méthylprednisolone ( $10 \mathrm{mg} . / \mathrm{kg}$.) et de l'ampicilline $(500 \mathrm{mg}$.) et 100 pour cent d'oxygène a été insufflé par le tube endotrachéal jusqu'au réveil complet de l'animal.

Les chiffres de la pression artérielle moyenne réflétaient assez bien les pertes de sang et le remplacement lors de l'usage d'anesthésiques halogénés à l'exception du fluroxène. Avec le thiopentone, l'innovar, l'ether diéthylique, le cyclopropane et le fluroxène, non seulement la pression sanguine ne s'abaissa pas proportionnellement à l'importance de la diminution du volume sanguin, mais elle revint à la normale et même au dessus de la normale dès qu'on eut remplacé partiellement le sang.

Le rythme cardiaque ne sembla pas indiquer de façon satisfaisante les changements de volume sanguin excepté lorsqu'on utilisa les anesthésiques intraveineux (Pentothal et innovar) et peut-être aussi le fluroxène et le trichloréthylène. L'électrocardiogramme n'a pas présenté de changements importants en rapport avec les différents anesthésiques ou avec le degré d'hémorragie. La secrétion urinaire à été supprimée par tous les anesthésiques et par les saignées. Ceci fut surtout évident avec l'éther diéthylique, le chloroforme, le trichloréthylène et l'halothane-éther azéotropique.

La saignée a provoqué une tendance à l'acidose métabolique durant l'administration de tous les agents donnés par inhalation sauf le cyclopropane. Les seuls changements métaboliques encore observés furent une élévation marquée de la glycémie durant l'éther diethylique et le chloroforme, et un excès de lactate durant l'éther diéthylique. Les taux sanguins d'histamine et de sérotonine ainsi que les taux plasmatiques des catécholamines n'ont pas varié de façon appréciable et il n'y eut aucune relation directe apparente entre les taux du sucre sanguin, des lactates, pyruvates et catécholamines.

Les animaux se sont réveillés en deça de une à trois heures après la réinfusion du sang et, invariablement, ils étaient cliniquement normaux et deça d'une journée après chaque épreuve. Selon toute apparence, cette réanimation rapide à la suite de l'agression associée hémorragie et anesthésie générale est attribuable en partie à l'usage d'une dose relativement considérable de corticoïdes et d'antibiotiques.

\section{ACKNOWLEDGMENTS}

The authors are grateful to John B. Henry, M.D., Benjamin Africa, M.D., George Mann, R.T., Christina Bisset, R.N., Enid Racz, R.T., and Phyllis DiRaddo, R.T., for technical assistance.

\section{REFERENCES}

1. Jomnston, I. D. A. Endocrine Aspects of the Metabolic Response to Surgical Operations. Ann. Roy. Coll. Surgeons. 35: 270 (1964).

2. Moore, F. D. The Effects of Hemorrhage on Body Composition. New England J. Med. 273: 567 (1965).

3. SELYE, H. The General Adaptation Syndrome and the Diseases of Adaptation. J. Clin. Endocrinol. 6: 117 (1946).

4. Ebert, R. V.; Stead, E. A.; \& Gibson, J. G. Response of Normal Subjects to Acute Blood Loss. Arch. Int. Med. 68: 578 (1941).

5. Brannon, E. S.; Strad, E. A.; Warken, J. V.; \& Merrin., A. J. Hemodynamics of Acute Hemorrhage in Man. Am. Heart J. 31: 407 (1946).

6. Padir, R. K.; Nanson, E. M.; \& LynN, R. B. Hemodynamic Changes in Graded 
Hemorrhage with Special Reference to the Peripheral Circulation. Ann. Surg. 148: $827(1958)$.

7. Smith, D. P.; Fabian, L. W.; \& Carnes, M. A. Comparative Evaluation of Fluothane and Cyclopropane Anesthesia during Hemorrhagic Hypovolemia. Anesth. \& Analg. 40: 137 (1961).

8. Chasnow, E. A.; Smart, H. S.; Henry, J. H.; Papper, E. M.; \& Nahas, G. G. Effect of Morphine, Meperidine and Thiopental on Hypovolemic Shock. Surgery, 55: 567 (1964).

9. ANDREws, I. C.; ZAUDER, H. L.; \& Oruxn, L. R. Methoxyflurane and Halothane Anesthesia During Controlled Bleeding in Dogs. Anesthesiology. 27: 207 (1966).

10. Heymans, C. \& NeI, E. Reflexogenic Areas of the Cardiovascular System. London: Churchill (1958).

11. HADDY, F. J.; SCOTT, J. B.; \& Molnar, J. I. Mechanism of Volume Replacement and Vascular Constriction Following Hemorrhage. Am. J. Physiol. 208: 169 (1965).

12. Ballinger, W. F; Vollenwemer, H.; \& Montcomery, E. H. The Response of the Canine Liver to Anaerobic Metabolism Induced by Hemorrhagic Shock. Surg. Gynec. \& Obst. 112: 19 (1961).

13. Danofr, D. S. \& Greene, N. M. Vasodilation and Metabolic Response to Hemorrhage. Surgery. 55: 820 (1964).

14. LundsGaAnd-Hansen, P. Oxygen Supply and Anaerobic Metabolism of the Heart in Experimental Hemorrhagic Shock. Ann. Surg. 163: 10 (1966).

15. Peterson, C. G. \& Havgen, F. P. Hemorrhagic Shock and the Nervous System. 1. Spinal Cord Reflex Activity and Brain Stem Reticular Formation. Ann. Surg. 161: 485 (1965).

16. Gerist, P. H.; Rattendonc, C.; \& Holaday, D. A. The Effects of Hemorrhage on Pulmonary Circulation and Respiratory Gas Exchange. J. Clin. Invest. 38: 524 (1959).

17. Crowell, J. W. \& SMrth, E. E. Oxygen Deficit and Irreversible Hemorrhagic Shock. Am. J. Physiol. 206: 313 (1964).

18. Nunn, J. F. \& Freeman, J. Problems of Oxygenation and Oxygen Transport During Haemorrhage. Anaesthesia. 19: 206 (1964).

19. Justus, D. W.; Connett, R. W; \& Hatcher, J. D. A Humoral Influence on Cardiovascular Adjustments to Acute and Chronic Posthemorrhagic Anemia in Dogs. Circulation Res. 5: 207 (1957).

20. Virtue, R. W. \& HetMich, M. L. Adrenal Response to Stress Before Operation, During Anaesthesia and During Surgery. Proc. Roy. Soc. Med. 49: 492 (1956).

21. GANN, D. S. \& EgDAm, R. H. Responses of Adrenal Corticosteroid Secretion to Hypotension and Hypovolemia. J. Clin. Invest. 44: 1 (1965).

22. Dogkin, A. B.; BYLEs, P. H.; \& Nevinle, J. F., JR. Neuroendocrine and Metabolic Effects of General Anaesthesia During Spontaneous Breathing, Controlled Breathing, Mild Hypoxia and Mild Hypercarbia. Canad. Anaesth. Soc. J. 13: 130 (1966).

23. Lillemei, R. C.; Longerbean, J. K.; Block, J. H.; \& Manax, W. G. The Modern Treatment of Shock Based on Physiological Principles. Clin. Pharmacol. \& Therap. 5: 63 (1964).

24. Maclean, L. D.; Duff, J. H.; Scott, H. M.; \& Peretz, D. I. Treatment of Shock in Man Based on Hemodynamic Diagnosis. Surg. Gynec. \& Obst. 120: 1 (1965).

25. Mallet-Gux, P.; Rousset, L. P.; \& Grgnoux, M. Experimental Study of the Cardiac and Cerebral Reanimation of the Dog in Apparent Death Following Hemorrhagic Shock: The Effect of Intra-arterial Transfusion of Oxygenated Blood and of Artificial Respiration. Lyon chir. 61: 223 (1965).

26. Price, H. L.; Linde, H. L.; Jones, R. E.; Black, G. W.; \& Price, M. L. Sympatho-adrenal Responses to General Anesthesia in Man and Their Relationship to Hemodynamics. Anesthesiology, 20: 563 (1959).

27. Darby, T. D. \& WATrs, D. T. Acidosis and Blood Epinephrine Levels in Hemorrhagic Hypotension. Am. J. Physiol. 206: 1281 (1964).

28. Wurtiman, R. J. Medical Progress: Catecholamines. New England J. Med. 273: 637, $693, \& 746$ ( 1965$)$.

29. Symposium on Catecholamines. Pharmacol. Rev. 18: March (1966).

30. DonknN, A. B. \& Byces, P. H. Comparison of Anaesthesia with Innovar, Halothane and Methoxyflurane-Nitrous Oxide. Acta anaesth. scandinav. 10: Suppl. XVIII (1966).

31. Whitley, L. G.; Axrl.rod, J.; \& Went-Malmerke, H. Fate of $\mathrm{H}^{3}$-Norepinephrine in Animals. J. Pharmacol. \& Exper. Therap. 132: 193 (1961).

32. AxELrod, J. O-methylation of Epinephrine and Other Catechols In Vitro and In Vivo. Science. 126: 400 (1957). 